\title{
The Effect of Extract Supplements of Moringa Oleifera Leaves Plus Royal Jelly on Hemoglobin (Hb) Levels of Anemia Pregnant Mother in Takalar Regency
}

\author{
Yulni $^{1}$, Veni Hadju ${ }^{1}$, Burhanuddin Bahar ${ }^{1}$, Citrakesumasari ${ }^{1}$, Rahayu Indriasari ${ }^{1}$, Zainal $^{2}$ \\ ${ }^{1}$ Departemen of Nutrition, Faculty of Public Health, Hasanuddin University, Makassar, \\ Indonesia \\ ${ }^{2}$ Department of Agricultural Technology, Faculty of Agriculture, Hasanuddin University, \\ Makassar, Indonesia
}

\begin{abstract}
The aim of this study was to determine the effect of Moringa oleifera leaf extract supplements, Moringa oleifera leaf extract plus royal jelly and placebo on hemoglobin levels in anemic pregnant women. This research is a randomized controlled double blind design study which was conducted in Polombangkeng Utara District, Takalar Regency for 2 months. The subjects of this study were pregnant women with anemia, the majority of which were 2035 years old, primigravida parity, income less than UMR, unemployment, higher education, pregnancy distance of more than 2 years with $\mathrm{p}$ value $>0.05$. Then divided into three groups, namely Moringa capsules plus royal jelly $(\mathrm{KRJ})(\mathrm{n}=24)$, Moringa capsules $(\mathrm{KTR})(\mathrm{n}=24)$ and placeco $(\mathrm{PLC})(\mathrm{n}=21)$. Before and after the intervention, measurements of hemoglobin levels were carried out using the Hemocue tool and interviewing the characteristics of the respondents. The results showed that the average $\mathrm{Hb}$ level increased from each group (mean $\mathrm{SD}$ ): KRJ $10.06 \pm 0.75$ to $11.42 \pm 1.23, \mathrm{P}=0.001$, KTR $10.40 \pm 0.46$ to $11.15 \pm 0,90 \mathrm{P}=$ 0.001 and PLC $10.43 \pm 0.42$ becomes $11.14 \pm 0.88 \mathrm{P}=0.002$. but there was no significant difference from the difference in the average increase in $\mathrm{Hb}$ levels in the three groups, but there was a tendency that KRJ was superior to the KTR and PLC groups with an increase of $1.36 \mathrm{gr} / \mathrm{dl}$, KTR $0.75 \mathrm{gr} / \mathrm{dl}$ and PLC $0.71 \mathrm{gr} / \mathrm{dl}$. So it can be concluded that KRJ is better than KTR and PLC in increasing Hb levels in anemic pregnant women in Takalar Regency.
\end{abstract}

Keywords: Moringa, Hemoglobin ( $\mathrm{Hb})$ Levels, Pregnant Women, Anemia

Received : October 26, 2020

Received in Revised: November 5, 2020

Accepted: November 9, 2020

\section{Introduction}

Pregnancy is an event that starts from the fertilization process (conception) to the birth of a baby. Gestational age ranges from 266-280 days or 37-40 weeks, various problems experienced by mothers during the pregnancy process, one of which is anemia (Hardiansyah \& Supariasa, 2014). The impact of anemia in pregnant women is very detrimental, anemia in antenatal care can affect babies born with low birth weight, placenta previa, eclampsia, and premature rupture of membranes, and even to fetal death (Smith et al., 2012; Masukume et al., 2015 ).

In Indonesia, the prevalence of anemia in pregnant women based on the results of Basic Health Research has continued to increase from year to year, where in 2007 it was $24.5 \%$, in 2013 it increased to $37.1 \%$ and in 2018 it was $48.9 \%$, which means that almost Half of pregnant women are at high risk of experiencing adverse pregnancy complications, the prevalence of anemia is almost the same between urban $(36.4 \%)$ and rural (37.8\%) pregnant women in 2013 based on Riskesdas. According to data in Takalar Regency in 2017, the 
number of anemia pregnant women was 142 pregnant women and an increase in 2018, namely 524 pregnant women. For the highest prevalence of anemia in Takalar Regency, there is North Polombangkeng District, where in 2018 anemia in pregnant women was $23.6 \%$ (Takalar Regency Health Office, 2019).

Moringa (Moringa oleifera) is a local plant that has been used as a multipurpose, nutrient dense and medicinal plant for centuries. Moringa leaves contain various kinds of nutrients and a source of phytochemicals. Moringa contains more and more various natural compounds than other plants. Research conducted by Nurdin et al, (2018) in Jeneponto where the sample was divided into 3 treatment groups, namely the intervention of moringa leaf powder, moringa capsule extract and iron folate, this study showed that the hemoglobin concentrations of the three treatments were equally increased, with an increase the biggest intervention in Moringa leaf extract intervention, it underlies that the use of Moringa leaf extract capsules can be used as an alternative as a supplementation program in the prevention of anemia.

Royal jelly is a product of the bee's cephalic gland secretion which serves as the most important part of the diet of honey bee larvae. royal jelly also contains Fe, copper, zinc, folic acid, vitamin B6 which can help the process of forming red blood cells, so that it can be used as an alternative in preventing anemia (Visweswara et al., 2017). Moringa and royal jelly contain substances that can form hemoglobin such as iron, vitamin $\mathrm{C}$, vitamin A, vitamin B12, folic acid. This is what underlies the researchers to make a study entitled "The effect of giving Moringa olifera leaf extract supplements plus royal jelly on the increase in hemoglobin in anemic pregnant women in Takalar Regency".

\section{Methods}

This type of research is an experimental study with a randomized controlled Double Blind Design. The study was conducted in Polobangkeng Utara District, Takalar Regency for 2 months from July to September 2020. The population in this study were all pregnant women in Polombangkeng Utara District, Takalar Regency.

The sampling technique in this study was the purposive sampling method that met the inclusion criteria and all of them still received a blood supplement containing $60 \mathrm{mg}$ of elemental iron (in the form of ferrous sulfate, ferro fumarate or ferro gluconate) and $0.25 \mathrm{mg}$ folic acid. from the government then divided into three groups, the KRJ group who received Moringa capsules plus royal jelly $(\mathrm{n}=24$ people), the KTR group who received Moringa capsules ( $\mathrm{n}=24$ people) and the PLC group who received a placebo containing starch powder $(\mathrm{n}=21$ person).

Data collection was obtained by conducting screening, interviews and direct measurements regarding identity, age, parity, occupation, family income, pregnancy spacing and HB in the research subjects. All data were analyzed using the SPSS program. In this study using bivariate analysis with the chi-square test and to assess the mean difference before and after the intervention using the paired test if it is normally distributed, the Wilcoxon test if it is not normal and the Mc Nemar test if it is categorized. To see the difference in the mean change between the three groups, the One Way Anova test was used if the data were normally distributed and the Kruskal Wallis test if it was not normal. Multivariate analysis was performed to determine which independent variables were more influential using the binary logistic test. 


\section{Results and Discussion}

\section{Characteristics}

Table 1. Distribution based on characteristics of respondents in the three groups

\begin{tabular}{|c|c|c|c|c|c|c|c|c|c|}
\hline \multirow[t]{2}{*}{ Variable } & \multicolumn{2}{|c|}{ 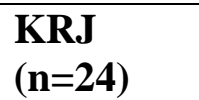 } & \multicolumn{2}{|c|}{$\begin{array}{l}\text { KTR } \\
(n=24)\end{array}$} & \multicolumn{2}{|c|}{$\begin{array}{l}\text { PLC } \\
(n=21)\end{array}$} & \multicolumn{2}{|c|}{ Total } & \multirow{2}{*}{$\begin{array}{l}\mathbf{P} \\
\text { Value }\end{array}$} \\
\hline & $\mathbf{n}$ & $\%$ & n & $\%$ & $\mathbf{n}$ & $\%$ & $\mathbf{n}$ & $\%$ & \\
\hline $\begin{array}{l}\text { Age } \\
\text { Low Risk } \\
\text { High Risk }\end{array}$ & $\begin{array}{l}19 \\
5\end{array}$ & $\begin{array}{l}79.2 \\
20.8\end{array}$ & $\begin{array}{l}18 \\
6\end{array}$ & $\begin{array}{l}75 \\
25\end{array}$ & $\begin{array}{l}16 \\
5\end{array}$ & $\begin{array}{l}76.2 \\
23.8\end{array}$ & $\begin{array}{l}53 \\
16\end{array}$ & $\begin{array}{l}76.8 \\
23.2\end{array}$ & $0.940^{\mathrm{a}}$ \\
\hline $\begin{array}{l}\text { Parity } \\
\text { Primigravida } \\
\text { Multigravida }\end{array}$ & $\begin{array}{l}17 \\
7\end{array}$ & $\begin{array}{l}70.8 \\
29.2\end{array}$ & $\begin{array}{l}17 \\
7\end{array}$ & $\begin{array}{l}70.8 \\
29.2\end{array}$ & $\begin{array}{l}12 \\
9\end{array}$ & $\begin{array}{l}57.1 \\
42.9\end{array}$ & $\begin{array}{l}46 \\
23\end{array}$ & $\begin{array}{l}66.7 \\
33.3\end{array}$ & $0.540^{\mathrm{a}}$ \\
\hline $\begin{array}{l}\text { Last Education } \\
\text { High } \\
\text { Low }\end{array}$ & $\begin{array}{l}17 \\
7\end{array}$ & $\begin{array}{l}70.8 \\
29.2\end{array}$ & $\begin{array}{l}15 \\
9\end{array}$ & $\begin{array}{l}62.5 \\
37.5\end{array}$ & $\begin{array}{l}13 \\
8\end{array}$ & $\begin{array}{l}61.9 \\
38.1\end{array}$ & $\begin{array}{l}45 \\
24\end{array}$ & $\begin{array}{l}65.2 \\
34.8\end{array}$ & $0.774^{\mathrm{a}}$ \\
\hline $\begin{array}{l}\text { Employment } \\
\text { Jobless } \\
\text { Working }\end{array}$ & $\begin{array}{l}19 \\
5\end{array}$ & $\begin{array}{l}79.2 \\
20.8\end{array}$ & $\begin{array}{l}21 \\
3\end{array}$ & $\begin{array}{l}87.5 \\
12.5\end{array}$ & $\begin{array}{l}18 \\
3\end{array}$ & $\begin{array}{l}85.7 \\
14.3\end{array}$ & $\begin{array}{l}58 \\
11\end{array}$ & $\begin{array}{l}84.1 \\
15.9\end{array}$ & $0.710^{\mathrm{a}}$ \\
\hline $\begin{array}{l}\text { Income } \\
\text { Low } \\
\text { High }\end{array}$ & $\begin{array}{l}16 \\
8\end{array}$ & $\begin{array}{l}66.7 \\
33.3\end{array}$ & $\begin{array}{l}19 \\
5\end{array}$ & $\begin{array}{l}79.2 \\
20.8\end{array}$ & $\begin{array}{l}20 \\
1\end{array}$ & $\begin{array}{l}95.2 \\
4.8\end{array}$ & $\begin{array}{l}55 \\
14\end{array}$ & $\begin{array}{l}79.7 \\
20.3\end{array}$ & $0.059^{\mathrm{a}}$ \\
\hline $\begin{array}{l}\text { Pregnancy } \\
\text { Distance } \\
<2 \text { Years } \\
\geq 2 \text { Years }\end{array}$ & $\begin{array}{l}7 \\
17\end{array}$ & $\begin{array}{l}29.2 \\
70.8\end{array}$ & $\begin{array}{l}4 \\
20\end{array}$ & $\begin{array}{l}16.7 \\
83.3\end{array}$ & $\begin{array}{l}3 \\
18\end{array}$ & $\begin{array}{l}14.3 \\
85.7\end{array}$ & $\begin{array}{l}30 \\
39\end{array}$ & $\begin{array}{l}43.5 \\
56.5\end{array}$ & $0.400^{\mathrm{a}}$ \\
\hline
\end{tabular}

Source: Primary Data, 2020

Table 1 below shows that none of the respondent characteristics variables are significant. For the age variable of 69 total respondents, the majority of whom were low-risk, including in the KRJ group 19 people (79.2\%), KTR there were 18 people $(75 \%)$ and 16 people $(76.2 \%)$ in the PLC group. Parity characteristics of the majority of the primigravida category, namely 17 people $(70.8 \%)$ in KRJ and KTR, while in PLC there were 12 people $(57.1 \%)$. Most of the latest education is high education, namely 17 people $(70.8 \%)$ in KRJ, 15 people $(62.5 \%)$ in KTR and in PLC there are 13 people (61.9\%). The majority of occupational variables are not working or as housewives, namely the KRJ as many as 19 people $(79.2 \%), 21$ people $(87.5 \%)$ in KTR and 18 people $(85.7 \%)$ in PLC. The majority of respondents have low income, in KRJ there are 16 people (66.7\%), 19 people (79.2\%) in KTR and 20 people (95.2\%) in PLC. In KRJ, the majority have pregnancy spacing $\geq 2$ years of 17 people $(70.8 \%)$ as well as in the PLC group there were 18 people $(85.7 \%)$ and in KTR the pregnancy interval $\geq 2$ years more, namely 20 people $(83.3 \%)$.

\section{Bivariate Analysis}

Changes in anemia status before and after the intervention in the three groups can be seen in the diagram below. It shows that the three groups have a $\mathrm{p}$ value of 0.001 , meaning that there is a significant difference before and after the intervention. In KRJ before the intervention as many as 20 people $(83.3 \%)$ had mild anemia and after the intervention 18 people $(75 \%)$ 
became normal. In KTR all respondents $(100 \%)$ had mild anemia and after the intervention 12 people $(50 \%)$ became normal. Likewise for PLC, all respondents $(100 \%)$ had mild anemia and after the intervention it became normal as many as 15 people $(71.4 \%)$.

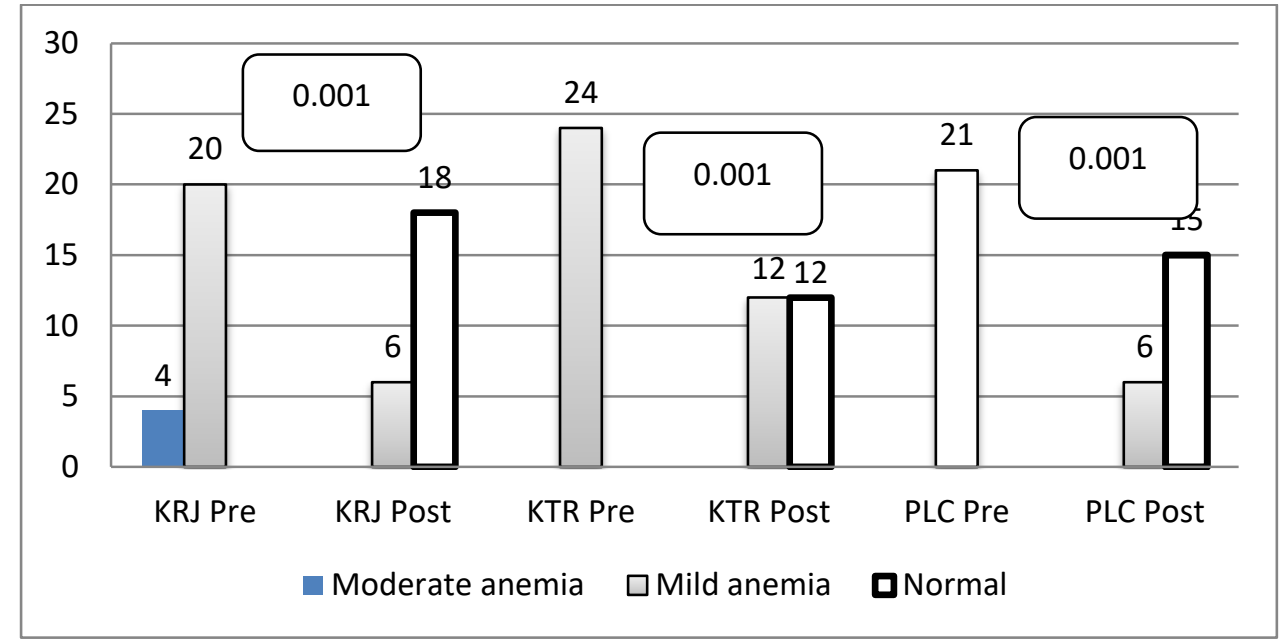

Figure 1. Diagram of Change in Anemia Status Before and After Intervention in the Three Groups

Analysis of the average $\mathrm{Hb}$ levels before and after the intervention of the three groups in table 3 below shows that KRJ and KTR have a p value of 0.001 while PLC is 0.002 , which means that there is a difference in the mean hb before and after the intervention in the three groups. In addition, there was an increase in the mean $\mathrm{hb}$, such as the KRJ from $10.06 \pm 0.75$ to 11.42 \pm 1.23 . On KTR from $10.40 \pm 0.46$ to $11.15 \pm 0.90$. While for PLC, it is from $10.42 \pm 0.44$ to $11.14 \pm 0.88$. Judging from the average increase in KRJ has the most increase, namely 1.36 \pm 0.48 compared to KTR which increased only $0.75 \pm 0.44$ and PLC $0.71 \pm 0.44$.

Table 3. Analysis of Average Hb Levels Before and After Intervention In the Three Groups

\begin{tabular}{|c|c|c|c|c|c|}
\hline \multirow[b]{2}{*}{ Variable } & Pre & Post & \multicolumn{2}{|l|}{$\Delta$} & \multirow[b]{2}{*}{$\begin{array}{l}\text { P } \\
\text { Value }\end{array}$} \\
\hline & \begin{tabular}{|l|} 
Mean \\
SD
\end{tabular} & $\begin{array}{l}\text { Mean } \pm \\
\text { SD }\end{array}$ & \begin{tabular}{|l|} 
Mean \\
SD
\end{tabular} & & \\
\hline $\begin{array}{l}\text { Hb levels (gr/dl) } \\
\text { KRJ } \\
\text { KTR } \\
\text { PLC } \\
\text { P Value }\end{array}$ & $\begin{array}{l}10.06 \\
0.75 \\
10.40 \\
0.46 \\
10.42 \\
0.44 \\
0.058^{b}\end{array}$ & $\begin{array}{l}11.42 \\
1.23 \\
11.15 \\
0.90 \\
11.14 \\
0.88 \\
0,673^{b}\end{array}$ & $\begin{array}{l}\uparrow 1.36 \\
0.48 \\
\uparrow 0.75 \\
0.44 \\
\uparrow 0.71 \\
0.44 \\
0,164^{\mathrm{c}}\end{array}$ & & $\begin{array}{l}\mathbf{0 . 0 0 1} 1^{\mathrm{a}} \\
\mathbf{0 . 0 0 1} \\
\mathbf{0 . 0 0 2} \\
\mathrm{a}\end{array}$ \\
\hline
\end{tabular}

Source: Primary Data, 2020

The average $\mathrm{Hb}$ before and after the intervention in the three groups increased. For more details, the average increase will be presented in the form of a diagram as below, it can be seen that the average increase in KRJ is superior, which is around $1.36 \pm 0.48$ compared to the other groups which is only $0.75 \pm 0.44$ for KTR and $0.71 \pm 0.44$ for PLC. 


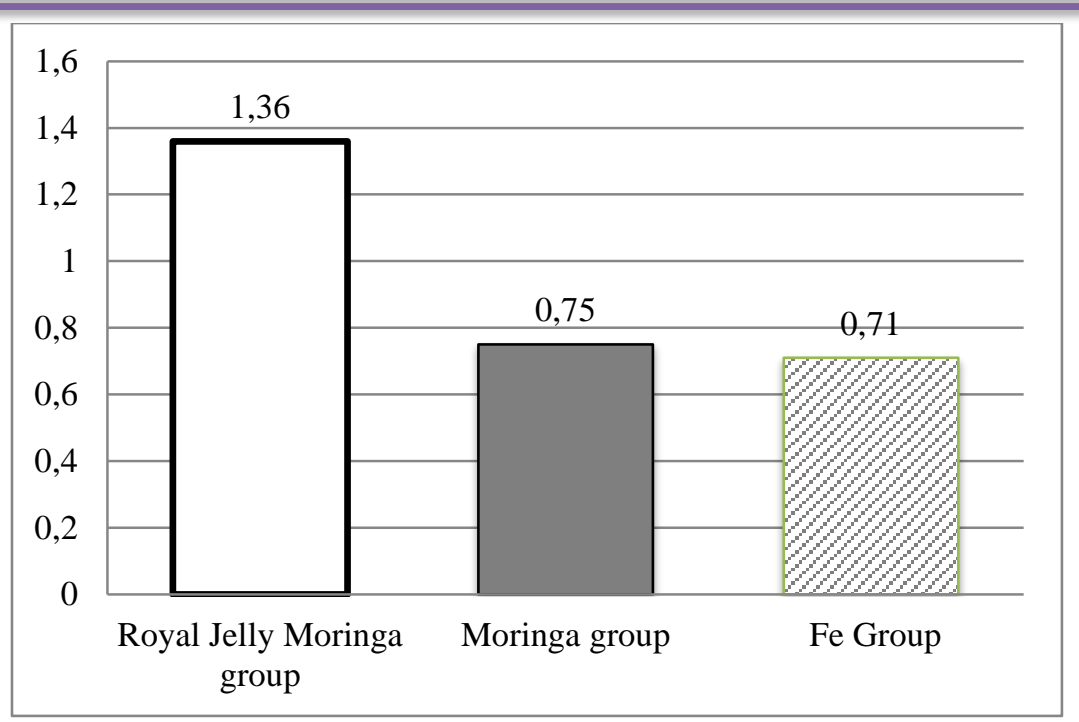

Figure 2. Diagram of the Difference in the Average Hb increase in the Two Groups

\section{Multivariate Analysis}

The results of the logistic regression analysis in Table 4 show that of the several risk factor variables for anemia, none of the respondent characteristics variables have an influence on the anemia status of pregnant women. For the variable age, having a $\mathrm{P}$ value of 0.176 and a value of $\mathrm{OR}=2.782$ is a risk factor and a CI value of $95 \%(0.631-12.263)$ so that the OR is not significant, so there is no difference in the risk of pregnant women suffering from anemia between pregnant women who have high risk age and low. The parity variable has a $\mathrm{P}$ value of 0.391 and the OR value $=0.553$ is not a risk factor and the CI value is $95 \%(0.143-2.141)$ so that the OR is not significant, so there is no difference in the risk of pregnant women suffering from anemia between pregnant women who have parity primigravida and multigravida. The education variable has a $\mathrm{P}$ value of 0.081 and $\mathrm{OR}=0.276$ which is not a risk factor and the CI value is $95 \%(0.065-1.174)$ so that OR is not significant, so there is no difference in the risk of pregnant women suffering from anemia between pregnant women who have high and low education. The occupational variable has a $P$ value of 0.180 and the $\mathrm{OR}=0.230$ is not a risk factor and the CI value is $95 \%(0.027-1.966)$ so that $\mathrm{OR}$ is not significant, so there is no difference in the risk of pregnant women suffering from anemia between pregnant women who work and do not work. The income variable has a $\mathrm{P}$ value of 0.137 and the $\mathrm{OR}=3,424$ is a risk factor and the CI value is $95 \%(0.677-17.331)$ so that the OR is not significant, so there is no difference in the risk of pregnant women suffering from anemia between pregnant women who have high and low income. The pregnancy interval variable has a $\mathrm{P}$ value of 0.291 and the $\mathrm{OR}=0.528$ is not a risk factor and the $\mathrm{CI}$ value is $95 \%(0.161-1.728)$ so that OR is not significant, it means that there is no difference in the risk of pregnant women suffering from anemia between pregnant women who have a pregnancy interval. less than 2 years and more than 2 years.

Table 4. Analysis of the Effect of Risk Factors of Several Variables on Anemia Status

\begin{tabular}{|l|l|l|l|l|}
\hline \multirow{2}{*}{ Variable } & \multirow{2}{*}{ OR } & \multicolumn{2}{|l|}{ CI 95\% } & \multirow{2}{*}{ P Value } \\
\cline { 3 - 4 } & & Lower & Upper & \\
\hline Age & 2.782 & 0.631 & 12.263 & $0.176^{\mathrm{a}}$ \\
\hline Parity & 0.553 & 0.143 & 2.141 & $0.391^{\mathrm{a}}$ \\
\hline Education & 0.276 & 0.065 & 1.174 & $0.081^{\mathrm{a}}$ \\
\hline Employment & 0.230 & 0.027 & 1.966 & $0.180^{\mathrm{a}}$ \\
\hline
\end{tabular}




\begin{tabular}{|l|l|l|l|l|}
\hline Income & 3.424 & 0.677 & 17.331 & $0.137^{\mathrm{a}}$ \\
\hline Pregnancy Distance & 0.528 & 0.161 & 1.728 & $0.291^{\mathrm{a}}$ \\
\hline
\end{tabular}

Source: Primary Data, 2020

In this study in North Polombangkeng, in table 1 there are several variable characteristics of the respondents studied such as age, parity, latest education, occupation, income and pregnancy interval and not a single variable is significant, meaning that all these variables are not significantly different and likewise. characteristics based on body weight, lila and hemoglobin levels before intervention were not significant differences between the three groups

The results of the analysis of the increase in mean hb levels in anemia pregnant women in table 3 show that KRJ and KTR have a p value of 0.001 while PLC is 0.002 , which means that there is a difference in the mean hb before and after the intervention in the three groups. In addition, there was an increase in the mean hb, such as the KRJ from $10.06 \pm 0.75$ to 11.42 \pm 1.23 . On KTR from $10.40 \pm 0.46$ to $11.15 \pm 0.90$. While for PLC, it is from $10.42 \pm 0.44$ to $11.14 \square 0.88$.

Although the hemoglobin level was not statistically significantly different between groups, it was considered to be related to the minimum number of samples that was still lacking, the low dose and the insufficient length of time. However, if seen from the average increase in KRJ has the most increase, namely $1.36 \pm 0.48$ compared to KTR which increased only $0.75 \pm 0.44$ and PLC $0.71 \pm 0.44$. This is in line with research (Arini, 2018) in Jeneponto, which states that Moringa leaf powder capsules have a greater effect on increasing hemoglobin levels than giving Fe capsules.

In addition, it can also be seen from the change in anemia status in the sample (table 2) the group treated with Moringa leaf extract plus royal jelly was better than KTR and PLC where the number of people suffering from anemia before the intervention was 4 people $(16.7 \%)$ who suffered from moderate anemia and 20 people $(83.3 \%)$ who had mild anemia, after the intervention it changed to 6 people (25\%) ( 2 of them from moderate anemia) had an increase in status to mild anemia and 18 people ( $75 \%$ ) ( 2 of them were from moderate anemia) to be normal. Meanwhile, in the intervention group with moringa, before the intervention, all respondents had mild anemia and no one had moderate anemia. After the intervention there were still 12 people (50\%) who had mild anemia and 12 others experienced an increase in status to normal. Likewise for PLC, the anemia status of respondents before the intervention, all respondents experienced mild anemia, and after the intervention 15 people $(71.4 \%)$ experienced an increase to normal and 6 other people did not experience an increase. According to research results (Hamzah \& Yusuf, 2019) Moringa leaves contain high Fe and can be used as an alternative to treat anemia in pregnant women naturally. Moringa leaf extract supplements are also considered to be more efficient in preventing anemia and can maintain normal $\mathrm{Hb}$ levels (prevent anemia).

According to research conducted by (Nurdin et al, 2018) in Jeneponto, it shows that the hemoglobin concentration of the three treatments, namely moringa leaf extract, moringa flour and iron / folate groups both increased hemoglobin, but the biggest increase was in the intervention of Moringa leaf extract. This underlines that the use of Moringa leaf extract capsules can be used as an alternative as a supplementation program in the prevention of anemia. Likewise research conducted by (Fauziandari, 2019), also said that consuming Moringa leaf extract can increase hemoglobin levels. Research conducted by (Ponomban, dkk., 2013), revealed that by giving Moringa capsules at a dose of 2 x 2 capsules / day (500 
mg per capsule of Moringa leaf powder) for 30 days can increase the hemoglobin concentration in anemic pregnant women. Research by Nadimin et al (2015) also supports that the benefits of Moringa leaves can be used as iron intake, when Moringa leaf extract is given to pregnant women there is an increase in hemoglobin which is equivalent to pregnant women who receive iron folate supplements. Likewise research conducted by (Iskandar et al., 2015) In Gowa Regency, Moringa leaf extract supplementation can increase hemoglobin levels in pregnant women. Meanwhile, from the results of this study in Takalar, the group that received Moringa capsules plus royal jelly had the highest increase in $\mathrm{Hb}$, namely $1.36 \pm$ 0.48 compared to other groups. This is because moringa and royal jelly are able to increase appetite and also contain substances that can form hemoglobin such as iron, vitamin $\mathrm{C}$, vitamin A, vitamin B12 and folic acid.

According to the results of research by Bhachandra et al (2018), the group of mice given royal jelly and honey showed a significant increase in all hematological parameters compared to the control group. The parameters referred to include the total number of white blood cells, red blood cells, hemoglobin percent, packed cell volume (PCV) value, average blood volume, and average blood hemoglobin.

By looking at the nutritional content of Moringa and Royal Jelly, this modification of Moringa and Royal Jelly is very useful in preventing iron deficiency anemia in pregnant women. In addition, according to Visweswara et al (2017), Royal jelly also contains Fe, copper, zinc, folic acid, vitamin B6 which can help the process of forming red blood cells. Apart from the nutritional content in Moringa and Royal Jelly, the absorption rate of iron sources from animal foods can be absorbed by $20-30 \%$ while iron from plant foods is only about $5 \%$.

\section{Conclusion}

The three treatment groups had an influence on hemoglobin levels, but if judged from the increase in the average hemoglobin level, the group given Moringa plus royal Jelly capsules had a greater increase in hemoglobin levels than the group given Moringa capsules and $\mathrm{Fe}$ capsules. It is recommended that you be able to make royal jelly moringa capsules or moringa capsules together with a blood supplement tablet so that the increase in $\mathrm{Hb}$ in pregnant women is maximized.

\section{References}

Arini, (2018). Pengaruh Pemberian Tepung Daun Kelor (Moringa Oleifera Leaves) Terhadap Peningkatan Kadar Hemoglobin Pada Remaja Putri Di Kecamatan Tamalatea Kabupaten Jeneponto. Thesis, Universitas Hasanuddin.

Bhachandra, W., Alqadhi, Y. A., \& Ninawe, A. (2018). Ameliorative role of bee honey and royal jelly against cisplatin induced Alteration In Hematological parameters in Male wister albino Rat. Int J Pharm Pharmaceut Sci, 10(4), 10.

Dinas Kesehatan Kabupaten Takalar. (2019). Profil Kesehatan Kabupaten Takalar Tahun 2019. Takalar: Dinas Kesehatan Kota Takalar. https://sirusa.bps.go.id/sirusa/index.php/sektoral/pdf?kd=8943\&th=2019

Fauziandari, E. N. (2019). Efektifitas Ekstrak Daun Kelor Terhadap Peningkatan Kadar Hemoglobin Pada Remaja Putri. Jurnal Kesehatan Karya Husada, 7(2), 24-29.

Hamzah, H., \& Yusuf, N. R. (2019). Analisis Kandungan Zat besi (Fe) Pada Daun Kelor (Moringa oleifera Lam.) Yang Tumbuh dengan Ketinggian Berbeda di Daerah Kota Baubau. Indonesian Journal of Chemical Research, 6(2), 88-93. 
Hardiansyah dan Supariasa. (2014). Ilmu Gizi Teori dan Aplikasi. Jakarta: Penerbit Buku Kedokteran EGC.

Iskandar, I., Hadju, V., As' ad, S., \& Natsir, R. (2015). Effect of Moringa oleifera leaf extracts supplementation in preventing maternal anemia and low-birthweight. International Journal of Scientific and Research Publications, 5(2), 1-3.

Masukume, G., Khashan, A. S., Kenny, L. C., Baker, P. N., Nelson, G., \& Scope Consortium. (2015). Risk factors and birth outcomes of anaemia in early pregnancy in a nulliparous cohort. PloS one, 10(4), e0122729..

Nadimin, H. V., As'ad, S., \& Buchari, A. (2015). The extract of moringa leaf has an equivalent effect to iron folic acid in increasing hemoglobin levels of pregnant women: a randomized control study in the coastal area of Makassar. Int J Sci Basic Appl Res, 22(1), 287-94.

Nurdin, M. S., Hadju, V., Zulkifli, A., \& Arundhana, A. I. (2018). The effect of moringa leaf extract and powder to haemoglobin concentration among pregnant women in jeneponto regency. Indian Journal of Public Health Research \& Development, 9(2), 262-267.

Ponomban, S. S., Walalangi, R., \& Harikedua, V. T. (2013). Efektivitas suplementasi bubuk daun kelor (moringa oleifera) terhadap peningkatan kadar hemoglobin pada ibu hamil yang menderita anemia. Jurnal Gizido, 5(1), 36-44.

Smith, J., Currie, S., Perri, J., Bluestone, J., \& Cannon, T. (2012). National programs for the prevention and management of postpartum hemorrhage and preeclampsia/eclampsia: a global survey, 2012. Baltimore: Maternal and Child Health Integrated Program.

Visweswara, R. P., Lakhsmi, S., Nagesvari, R., \& Siew, H. G. (2017). Honey, propolis, and royal jelly: a comprehensive review of their biological actions and health benefits. Oxidative Medicine and Cellular Longevity, 2017, 1259510. 